\title{
Understanding of the Meaning of Leadership from the Perspective of Muslim Women Academic Leaders
}

Samah Hatem Almaki

almakisamah@gmail.com

\author{
Prof. Dr. Abu Daud Silong
}

abudaud.silong@gmail.com

Prof. Dr. Khairuddin Idris

Dr. Nour Wahiza Abd. Wahat

University Putra Malaysia, Department of Professional Development and Continuing Education

Doi:10.5901/jesr.2016.v6n2p225

\begin{abstract}
Leadership, as one of most widely discussed and researched issues, has been characterized by a variety of definitions, frameworks, and meaning. Such definitions and notions provide a foundation for developing effective leadership in various organizational environments. This paper discusses the meaning of leadership from the perspective of Muslim women leaders in higher education by using a qualitative method and in-depth interviews from selected participants from University Putra Malaysia and King Abdul-Aziz University. The research attempts to answer questions like: what does leadership mean? How can Muslim women leaders become effective leaders in higher education? Findings of the study indicate that there is no difference between both groups of Muslim women leader in understanding the meaning of leadership. It was also found that leadership is strongly linked with vision and goal setting, accountability, role model, engorgement, and empowerment. Finally, implications are put forward to improve the potentiality of Muslim women leaders in different ways.
\end{abstract}

Keywords: leadership, effective leadership, effective women leaders, higher education.

\section{Introduction}

In a few decades, women's leadership studies have changed the understanding of leadership concept. In particular, the developed paradigms in feminist studies have introduced as problem-solving stance which strives to promote socially useful ends and new models of leadership (Astin \& Leland, 1991). More and more women have appeared on international arenas as successful leaders, and this trend can be interpreted as a great step towards providing equal opportunities for women to overcome the existing prejudices (Shahtalebi, Yarmohammadian \& Ajami, 2011).

Understanding the meaning of leadership is highly important towards testing and analyzing the related theories (Avolio \& Gardner, 2005). According to Yukl and Fleet (1992), leadership is necessary to shape the goals, coordinate the efforts, motivate the employees, and monitor the performance. Subsequently, it can be perceived differently if reviewed from different perspectives, especially from regional, religious, cultural, political and economic angles (AlSarhi, Salleh, Mohamed \& Amini, 2014). Richardson (2000), as well explained that we can achieve a better understanding about groups and communities by looking at their leaders. Moreover, leadership consists of the efforts of one member of an organization with respect to other members to help them achieve their goals. Leaders try to guide firms and their people to build their future because this is their responsibility to find new paths in changing organizations and be persistent in pursuing the chosen direction (Won-joo \& Mulhern, 2009). Therefore, we often observe and study leaders since we know that having effective leadership is essential for our future career success. Academic leadership, as a special type of general leadership in higher education, refers to leadership in academic settings or institutions (Sathye, 2004). The study of leadership in higher education is important not just for institutional effectiveness, but because higher education plays a significant role in shaping the leadership in large societies (Astin \& Astin, 2000).

Leadership could be studied from various perspectives includes social, religious, political, and corporate. 
Therefore, the main objective of this article is to understand the meaning of leadership from the perspective of Muslim academic women's leaders. The paper starts with a brief review on the definition of leadership and the notion of effective women's leaders in higher education. Followed by the research methodology, findings, discussion and finally conclusion and recommendations of the study.

\section{The Notion of Leadership}

Despite the fact that leadership doesn't have a one-size-fits-all definition, its study could provide such a valuable insight for future research. Subsequently, learning about the exercise of leadership could also serve as a lens through which social situations can be observed (Astin \& Astin, 2000). Many researchers have investigated the notion of leadership across various disciplines (e.g., psychology, sociology political science, and economics) and from numerous theoretical perspectives (e.g., trait, behavioral, contingency, relational, information-processing, transactional, transformational, charismatic, and shared). (Day \& Antonakis, 2012). Nye (2008) proposed three elements for leadership: leaders, followers, and context. This study mainly concentrates on clarifying the reason for followers to follow someone lies in their need for meaning and belonging to a group in order to get the work done.

Some people may think that leadership means to influence others in order to complete a particular task, and thus it gives the ability to transform and influence people and institutions (Astin \& Astin, 2000). For example, Northouse (2010) defines leadership as "a process whereby an individual influences a group of individuals to achieve a common goal" ( $p$. 3). Similarly, Yukl (2010) provides the definitions of leadership as "...a process whereby intentional influence is exerted over other people to guide, structure and facilitate activities and relationships in a group or organization" (p. 21). Consequently, leadership can be understood as both an influential process and a specialized role held by an individual (Tafvelin, 2013).

Others, in the same manner, believes that leadership means to motivate the members of your team to do their best. It is also to inspire others to pursue your targets based on the parameters you set, and to the extent it becomes a shared effort, vision, and success (Zeitchik, 2012). While in the other hand, Kruse (2013) defined leadership as a process of social influence, which maximizes the efforts of others towards the achievement of a goal. While the definitions may vary, the general sentiment remains the same: leaders are those people who know how to achieve goals and inspire others along the way. Abd Aziz (2000) stressed that leaders, whose work is to make a difference, might face many challenges in their competition and success which causes a lot of discomfort. Therefore, in making a change, leaders must have an intellectual strength and sharpness in analysis to develop a vision and enable themselves to outline the goals clearly.

The leader, in the literature, has to adjust all the elements of his/her responsibility according to the guidelines of his/her organization (Kraines, 2001). Matei and Vazquez-Burguete (2012) define leadership as something "about articulating visions, embodying values, and creating the environment within which things can be accomplished" (p. 206). According to Bush (2003), there are three dimensions that form the basis of this definition which are leadership as influence, leadership and values, and leadership and vision. Some scholars see leaders as servants. In this line, Crippen (2005) points out that the primary purpose of servant leaders is to help rather than lead. According to Bijur (2000, p.167) "leadership means enhancing human potential". It is about creating the right environment for people to develop their ability as leaders.

\section{The Notion of Leadership in Islam}

The notion of leadership has attracted a considerable attention in Islam. It perceives to be one of the most significant instruments for the realization of an ideal society. Leadership in Islam "as a bridge that is used by the leader to influence the behavior and attitude of its members so as to achieve the goals of the organization" and the leader must be a visionary leader to guarantee the success of the organization (Ahmad, 2009 cited from Ali, 2007). From the very beginning, Islam has long considered leaders as servants. Prophet Muhammad (pbuh) put down the general principle when leading others as "On a journey, the leader of the people is their servant". In Islam, Quran praises selflessly altruistic people "and give them [emigrants] preference over themselves, even though they were in need of that," (Surat AlĤashr: 9). (Al Sarhi, Salleh, Mohamed \& Amini, 2014). Leadership in Islam is a matter of trust (amanah). It represents a psychological contract between a leader and his followers and shows his attempt to guide, protect and treat them with justice. Hence, the focus of leadership in Islam is on doing good things (Beekun, \& Badawi, 1998). 
Table 1: Leadership definitions

\begin{tabular}{|c|c|c|}
\hline Author & Years & Definition \\
\hline Beekun \& Badawi & 1998 & $\begin{array}{l}\text { "Leadership in Islam is a matter of trust (amanah). It represents a psychological contract between a leader } \\
\text { and his followers and shows his attempt to guide, protect and treat them with justice. Hence, the focus of } \\
\text { leadership in Islam is on doing good things" }\end{array}$ \\
\hline Bijur & 2000 & "leadership means enhancing human potential" \\
\hline Bush & 2003 & "leadership as influence, leadership and values, and leadership and vision" \\
\hline Crippen & 2005 & "Leaders as servants. Servant leaders primary believe in helping rather than leading" \\
\hline Ali & 2007 & $\begin{array}{l}\text { "leadership in Islam as a bridge that is used by the commander to influence the attitude and behavior of its } \\
\text { members so as to achieve the goals of the organization" }\end{array}$ \\
\hline Northouse & 2010 & "Leadership is a process whereby an individual influences a group of individuals to achieve a common goal" \\
\hline Zeitchik & 2012 & $\begin{array}{l}\text { "Leadership means to motivate the members of your team to do their best. It is also to inspire others to } \\
\text { pursue your targets based on the parameters you set, and to the extent it becomes a shared effort, vision, } \\
\text { and success }\end{array}$ \\
\hline $\begin{array}{l}\text { Matei \&Vazquez- } \\
\text { Burguete }\end{array}$ & 2012 & $\begin{array}{l}\text { "Leadership as something "about articulating visions, embodying values, and creating the environment within } \\
\text { which things can be accomplished" }\end{array}$ \\
\hline Kruse & 2013 & $\begin{array}{l}\text { "Leadership a process of social influence, which maximizes the efforts of others towards the achievement of } \\
\text { a goal" }\end{array}$ \\
\hline
\end{tabular}

The differences in defining the concept of leadership or the role of leaders not only reflect deep disunity among leader scientists, but also result in how different scholars interpret observations about leadership. Nevertheless, most of the experiences in leadership are seen as a profound reality in our daily life and work. Yukl (2006) believes that leadership, besides being a social construct and a real phenomenon for creating effective organizations, has benefits for scientific studies.

\section{Effectiv Leadership}

Effective leadership is sometimes difficult to define since it is built upon many variables and characteristics influencing the way it is measured as effective or ineffective. Individual perceptions of effective leaders are based on what these leaders say and do; that is, perceptions are grounded on the direct or indirect experience of the individual with the leader's behavior (Rosser, 2003). Leadership implies issues like values, creativity, intellectual drive and knowledge, selfconfidence, ethics, courage, charisma, etc. Basically, a good leader needs to have a purpose as well as a balanced personality and skills to put that purpose into action (POPA, 2012). According to Kaplan (1996) there are more than one way to define the efficiency of leadership'. Fundamentally, it possesses the characters which help to take the company vision forward, knowing how to adapt the leadership styles with the followers' development and the right time to apply each style. Blanchard (2008) indicated that effective leaders adapt their style according to the development level of the people they are managing.

Successful leaders should be flexible and adjust their styles constantly as both followers and situations change over time in work environment. Situational leadership argues that in order to be effective managers we need to adapt our styles according to the maturity of our people to carry out the task they are working on (Mark, 1997). One key element in effective leadership is inspiring a shared vision, which is a major element of change in the process of providing orientation and engaging the whole system (Lukas, els., 2007). Sousa (2015) explains leaders need to determine where they want the organization to go and how they will get it there. To know where they are headed, leaders must "assess, analyze, plan, evaluate and implement and. However, to achieve such effectiveness in leadership practices, there needs to be a shift from hierarchical approaches to leadership styles that encourage shared governance and facilitate staff empowerment (Williamson, 2005). Thus, effective leadership is not simply the result of obtaining a position, but rather possessing the knowledge and understanding of successful leadership skills along with the personal ability to effectively implement those skills (Sharma, Sun \& Kannan, 2012).

\section{Higher Education}

Higher education always has a major role to play in the development of the society, it helps in creation of new knowledge, transfer it to students and further promotes creativity and innovation (Zughoul \& Hussein, 1985). Goodchild (2002) defined higher education as a field of study that included "sophisticated knowledge about and research on colleges, universities, and related postsecondary institutions, as well as the professional skills used by those persons 
who work in them" (p. 303).

Higher education more important than other institutions given their pivotal role in society and the economy (OBE, 2013). Moreover, higher education keen to achieve the best level of quality in all areas of work, so the continued vitality of these institutions depends on the extent to keep pace of new and appropriate for the environment, And the extent to achieve the advancement of a knowledge and what they're doing scientific research and academic supervision, It is the elements that constitute the core of university life, by Universities alone can achieve the development, Upgrade Intellect, advancing science and grow human values, and it provides the human knowledge assets and advanced research methods (Schafer, 2000).

Over a period of time higher education has seen a gradual change in its leadership pattern (Altbach et al, 2009. Leadership in higher education is different from other organizations, especially corporate institutions, because it is effectively vested in a single person the Rector or Vice-Chancellor (VC). Furthermore, it is based on personal authority and expertise, experience, peer and professional, and discipline knowledge, recognition (Yielder \& Codling, 2004). Joyce (2013) believes that at the heart of academic leadership are academic values and identities, and the carving out and pursuing a particular line of scholarship rather than direction and control of academic work. This type of leadership could be collegial, with mutual support from staff, consensus decision-making, and debate and discussions with peers, as opposed to a bureaucratic controlling environment or managerialism

Furthermore, Vilkinas, Leask \& Ladyshewsky (2009) indicated that academic leadership requires depth and breadth of skills and knowledge, and is defined as a whole through a complex set of behaviors. Gardner, Avolio, and Walumbwa (2005), believe that the standards of behavior of the leader are congruent between what they do and what they declare, this is required from the leader in higher education due to their role in nation-building and human capacity development.

\section{Successful Women Leaders in Higher Education}

It is generally argued that men and women are biologically varied and thus suited differently for leadership. Researchers began to investigate and compare the effectiveness of leadership between men and women from various perspectives. This issue has raised a considerable interest and related debate among those scholars who studied the variations between men and woman leaders. Despite a lack of evidence, it is generally inferred that female leaders underrate their leadership (Abu-Tineh, 2013). Joasil, (2008) states that in general women are seen less likely to display effective leadership behaviors, as such receive lower performance evaluations by women and men subordinates alike. Women unlike men experience a double bind in leadership. When a woman promotes herself, she becomes less likeable. However, when she does not affirm her authority, she is regarded as less competent. Similarly, Dahlvig \& Longman (2010) \& Eagly \& Carli (2007) pointed out that when women in leadership positions do not exhibit the qualities, they are typically considered feminine, and in some occasions inadequate, unsuccessful, and less capable. In a study by Morley\& Crossouard (2014), it was found that women are not fully prepared for leadership. There is also an evidence that when women aspire for leadership positions, they are normally rejected from the most senior positions. However, it was also found that many academic women are reluctant to seek for senior leadership positions and perceive them as unattractive career options.

Despite research showing that men may be perceived as better appropriated for and more effective as leaders than women (e.g., Eagly, Makhijani, \& Klonsky, 1992; Carroll, 2006), some publications have reported the contrary: that there may be a women gender feature in modern organizations that require a "feminine" type of leadership (e.g., Conlin, 2003; Williams, 2012). Paustian-Underdahl, Walker \& Woehr, (2014). In the same context, Cole (2004) pointed out that despite the limited number of leadership positions assigned to women, they make effective contributions to the development of society. One concern regarding women leadership is the lack of data and related research on how women behave in such situations. Williams (2012) agreed with Cole, he noted that there needs to be an advantage concerning female gender in modern organizations that requires a "feminine" type of leadership. In the same line, BilenGreen, Froelich and Jacobson (2008) argued that women in senior academic positions can facilitate institutional change and develop women's professional recruitment and progression. They believe that the more women in leadership situations, the greater their understanding of real work policy obstacles, such understanding would promote networking possibilities and shift the organizational culture which can equalize academic involvement between men and women. Hence, having more women in academic leadership positions may provide a vigorous signal for the desired changes in the current culture. Walker (2004) consents with Marshall (1986) on the idea that 'women are very similar to men in their leadership styles and some of them may even possess superior positions in the areas related to management. 
In general, women as a leader's experience different realities and interpret them differently compared to their male counterparts, who deal with more traditional groups within higher education (Unin \& Dirkx, 2011).

\section{Methodology}

\subsection{Study Design}

The main purpose of this study is to understand how Muslim women academic leader perceive the meaning concept of leadership. In this light, the study uses a combination of research methods and approaches to answer the research questions outlined. The study also employs a qualitative research method in an attempt to describe situations and challenges that Muslim women face in higher education. According to Willig (2001), qualitative research seeks to understand the experiences from the participant's perspective, and acknowledges that the researcher's experiences and being bias are inseparable parts of the analysis process, and thus lead to better interpretation of the participants' responses. The study also incorporates a case study method to deal with the research problem. Two different case studies done in Malaysia (University Putra Malaysia) and Saudi Arabia (King Abdul Aziz University) were utilized by this research. Case studies are the preferred strategy when (why) or (how) questions are being posed, when the investigator has little control over events, and when the focus is on a contemporary phenomenon within some real-life context. A study that contains more than one case is called a multiple-case study (Yin, 1994). This study is also considered as a multiple-case study because it uses two case studies.

\subsection{Participants}

Qualitative research methodology is asserted by Merriam (1988). For Merriam (1988), qualitative research methodology focuses on quality rather than quantity. Merriam (1988) assumes that the main goals of investigation in qualitative research methodology are understanding, discovery, description, and hypothesis generating. The other factors that distinguish qualitative methodology from other methodologies are its setting which is often familiar and natural, a sample which is theoretical and non-random, and the researcher is treated as the primary instrument of data collection Merriam (1988). This data is collected through the use of interviews and observations, and the mode of analysis is inductive. Merriam explained that purposive sampling is based on the assumption when one wants to discover, understand, gain insight; he needs to select a sample from which he can get the most (p. 48). To this aim, the participants of this study were also chosen through purposeful sampling by drawing on 10 in-depth interviews with Muslim women who work in higher education. They were from different faculties such as, education studies, human ecology, modern language and social science faculties of two universities, namely University Putra Malaysia (UPM) and King Abdul-Aziz University in Saudi Arabia. The participants were all deputy dean and head of the department who have more than one year of leadership experience and thus would be able to explain and describe their experiences.

\subsection{Data Collection}

The data used in this study were generated using an interview guide developed by the researcher. In-depth interviews were conducted on the ten respondents gave detailed description of the meaning of leadership from their prospective. The interview lasted between 45 to 90 minutes and, were made at the leadership at locations of their conveniences which were their offices in University Putra Malaysia (UPM) and King Abdul-Aziz University (KAU) in Saudi Arabia. The advantage of semi-structured interview is that it helps facilitate rapport and empathy which lead to gaining rich and interesting data (Smith, Flowers, \& Larkin, 2009). The in-depth interviews dealt with broad and open areas such as asking participants about being leaders and also help them find a way to express their thoughts. In this study, the interview protocol provided a consistent framework; including the topics like participants' definition of leadership, their experiences about leadership, sources of discouragement and encouragement on the leadership journey, and suggestions and hopes for the future. All the interviews were recorded, allowing the researcher to take necessary notes and guide the subject into deeper areas or those areas that appeared to be superior to the current subject. Once the interviews were collected, the researcher repeated the recordings and reviewed the notes to see what main themes were emerged and what else needs to be altered regarding their format and content in order to be used for next interviews. 


\subsection{Data Analysis}

One feature of Qualitative data analysis is that it begins from the very beginning of research project prior to collecting data (Berg, 2007). The process of qualitative analysis often begins during the early stages of data collection. Memo writing and coding are considered as the most important techniques used in qualitative data analysis. In this study, the interview was recorded, transcribed verbatim, coded and analyzed according to themes. The process of coding the qualitative data involved organizing them into themes and data reduction; thus drawing a link between themes to arrive at possible conclusion and verification. Finally, a number of ways were suggested to ensure the validity and reliability of the data. To guarantee the validity of the study, some verification procedures were incorporated, including the compilation of a triangulation, filed note and member checking (Merriam, 2009) by summarizing the key points of discussions and asking participants for clarification, confirmation, and completion. After the discussion, the participants began to exchange their overall impressions and key insights as the first step in analysis.

\subsection{Ethical Considerations}

Ethical consideration deals with voluntarily involvement of the participants in the study. This includes designing informed consent procedures to provide Muslim women academic leaders and their team with sufficient information to raise their awareness towards the potential risks and benefits of participation in the interviews. The study follows the principles of confidentiality and, as such, all the statements that participants made during the qualitative phase were kept anonymously and appropriately. Women leaders selected a pseudonym from a list of names and used them in the transcripts to guarantee confidentiality. Necessary permissions were obtained from the participants and Universities.

\subsection{Finding}

This section presents the findings regarding the understanding of Muslim women academic leaders about leadership. This is accomplished by generating ideas and eliciting information from participants about their understanding of leadership and the effect of Muslim women in achieving leadership positions in higher education. The Data from various sources were analyzed using constant comparative methods. The women leaders in this study shared their experiences about leadership in their personal and professional lives. All the participants agreed that leadership is not just about power and authority, but it is a set of characteristics that should be owned by the leader. As a result, the five major themes which were emerged from the leadership of Muslim women are: vision and goal setting, accountability, role model, engorgement, and empowerment.

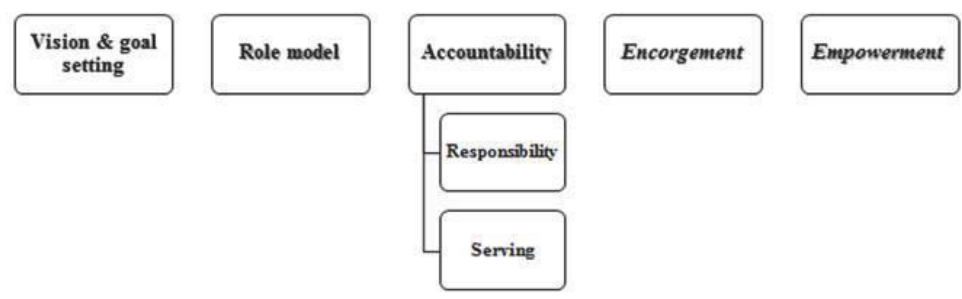

Figure 4. Core themes and categories of leadership meaning for Muslim women academic leaders.

\subsubsection{Theme 1: Vision and goal settings}

The first step in developing the aspect of leadership competency is to recognize the visioning, goal-setting, and planning. Both short- and long-term goals should accompany a vision (Turner, Norwood \& Noe, 2013). Effective leaders know how to achieve their goals and inspire and shared vision, which is a major element in the process of change in terms of providing orientation and engaging the whole system in practice (Kruse, 2013 \& Lukas et al., 2007). For three Muslim women leaders from two cases, the definition of leadership for women was very similar. Leadership was seen as a vision to make plan and give others a goal to help them reach their goals. Thus, vision can be considered as the first step in setting the goals. Therefore, the role of Muslim women leaders in conceiving and articulating this vision embodies the 
goals of organizations in applying them according to the rules and regulations that improve the section. Mai Malaysian women said:

"Leadership is make the organization in harmonious. Harmony means everybody works according to the mission in order to achieve the vision." (Mai)

Additionally, Saudi case have the same view of the meaning of leadership, Daw stated:

"Leadership is a vision, a message and an ambition to move the sector to better achievement. That is to achieve a quality in the educational process and to exploit the best available potentiality in the sector" (Daw)

Also other leader from Saudi agree with Daw, she arrested the important of achieve the goal according to rules and regulation, she said:

"Leadership means you wish to achieve a certain target and particular strategy, you applied in accordance with the rules and regulations. Leadership for me is a way to achieve a specific plan or strategy to achieve department goals and solve problem, then deliver to other person to complete the mission" (San)

\subsubsection{Theme 2: Being a role model}

Role models function as a crucial factor at the interpersonal level. In order to inspire others and build a community that works together, professionals should have the natural ability to provide positive samples for their team. On the other hand, role models are extremely fruitful ways in inspiring women to seek their goals. For the Muslim women leaders, role models are mostly referred to those models that can be found close to their home or in the people around them. During the course of interviews, four Muslim women from two countries attested that leaders should be a good example as a role model. They believed that to be a good leader, it is important to live and act as an example because leaders deal mostly with human, and when people see their act they follow them. In this line, two of the participants from Malaysia stated:

"Leadership have to be a good Muslim so when you give a responsibility of another human being, you have to show at most responsibility because you have to fulfill applications to answer to whatever needs" (Nob)

Int has same understanding:

"For me being leadership is being an example. It's a living as an example, you have to be humanist. Being human is easy but being humanist is not easy. Humanist is something else" (Int)

Women leader in Saudi have the same understanding, Daw said:

"Leadership means; I must be a good example in my work, uniformity. I must be sure of taking proper procedures and following-up to my duties." (Daw)

Nai had working in the same university as a leader and she agreed with her colleague Daw in the same opinion about understanding of the meaning of leadership, she said:

"I have to be good example. Be good example is very important and this happened when people see your commitment in all things especially commitment in the teachings of Islam that it require from you as a leader in terms of who you are, your speech, your talk, your simplicity." (Nai)

All the participants in the study were asked to specify the best example for them. They explained the reason for their choice, as some people are a good example because of their leadership style and qualities which make other people to follow them. Virtually, the Prophet Muhammad is considered as the role model for most of women leaders because of the way and behavior in which he leads the nation. It is generally accepted that if Muslim women follow his style and ways in leadership, they can become a good and effective leader: Mai described:

"In Islam of course our Profit, because Allah is giving him especial quality and we should follow whatever he embraced last time in terms of the actions, human relations, and also someone in Islam must adhere to the norms and principles 
and tenets of Islam".(Mai)

Waf provided her good example by describing his style:

"My good example is Prophet Mohammed (pbuh). I always said for my students, if we have the morel of Prophet Mohammed, everything will be good. All the lessons that he taught us such as, shura, patience, good dealing with those who he does not love them or love them, friend and enemy. Actually, he has a perfect method to lead others." (Waf)

In addition to the Prophet Muhammad set an example for Muslim women leaders some of women leaders that the most influential group of people for their careers had been higher-level managers, Int said:

"There is a professor in USM, now she is in the ministry of education, she is a professor Asma Ismael. The way she works, she is very strong and she effected to be different" (Ini)

Although San was quick to acknowledge that she has learned a great deal from good dean, who have influential and psychologically stable. She described:

"I think that Dr. Noura Al al-Sheikh is a good example for me in leadership. She assumed the dean position in women's colleges. She was very influential, psychologically stable and successful leader, she wasn't a bossy leader, she was influential, in contrast her administration was stable and she had a big role at the university (San)

\subsubsection{Theme 3: Accountability}

When defining leadership, the general theme which is utilized by women leaders in this study was Accountability. Accountability is defined as the ability to respond and take responsibility over one's action in a transparent manner. It also involves the readiness to suffer from the consequences or conversely take credit (Hall, Blass, Ferris \& Massengale, 2004). Here, accountability does not involve reporting or monitoring. Participants pointed out to two types of accountability which are responsibility and serving.

\subsection{Responsibility}

Three Muslim women from the two cases contended that leadership is a responsibility which needs time to perform. It requires the women leader to be answerable to God, work and people because she will be questioned it in front of Allah. One the other hand, despite the burden and responsibility imposed by leadership, women referred to positive escape of this responsibility which is to gain experience. According to Nob perspective about leadership meaning:

"For me leadership means responsibility. Leadership is not a glorified tittle for me, for me, it's a huge responsibility that at the end of the day, whether I finish my term, whether I fill full my role as a human being, I am answerable to God I am answerable to what I have done, so it's a huge responsibility that I will not be able to do it alone" (Nob)

Aber from Saudi has the same understanding of leadership meaning:

"Leadership is an assignment and responsibility. Even when they were congratulating me, I told them pray for me instead congratulate me. A lot of women don't like this post because it is responsibility and burden but at the same time it has a lot of experiences... "I fear from Allah because it is the responsibility, I will ask about it in front of Allah. The Prophet, may Allah bless him and grant him peace, "All of you are shepherds and each of you is responsible for his flock". Now the shepherds become bigger than before and it's important to take care for flock." (Abe)

\subsubsection{Serving}

To women, leadership mostly has to do with commonsense and helping others to understand their own situation, obligation and place in the world. It is clearly based on providing service to others (Hassan \& Silong, 2008). Three participants agreed with the current definition of leadership. They define leader as someone who provides service to several sides, primarily to Allah by fulfilling applications. She also provides service to university by equipping people with training, tools, time, and energy, so that they can exploit their full potential, both professionally and personally. Nob concluded her understanding by saying: 
"Anything that's given to me because first of all being servants of Allah means you have to fulfill your applications. (Nob)

According to Nai's philosophy, leadership mean is:

"It's an assignment, an assignment to service the college that I love it, to place I was a student in the Bachelor level in it, so I want to provide something to people that I work for them by giving them training and time to benefit from their potential" (Nai)

\subsection{Theme 4: Encouragement}

An effective leader is responsible for creating a framework which encourages others to tap into their own skills and ideas and freely contribute them to the project or company. To three Muslim women in Saudi and Malaysia, leadership pushes others to work effectively and take advantage of their potentials for change and achieve the mission of the organization. One of the participants confirmed that loyalty to the organization helps to solve the problems they face. Nob from Malaysia labeled her understanding by saying:

"Leadership is encouraging other to make change. Sometimes you go against the mainstream in term of idea, but I am one of those who likes to try to encourage to make changes, you also have to be responsible for any consequences" (Nob) saying:

Similarly, Daw from Saudi has same view, she made clear her understanding of the meaning of leadership by

"Leadership is encouraging other to take advantage of all the capabilities available in your sector, selection of active members, encourage teamwork and build others opinions to your vision and your message, this very important for leader". (Daw)

Waf also agree with her collogues Daw, she said:

"Leadership is pushing others to work effectively and loyalty to the place because when there is a loyalty to the place or to the group that they work, every problem can solve. Women leaders should know the quality of the individuals whom they deal with. They have to encourage them to work" (Waf)

\subsubsection{Theme 5: Empowerment}

Empowerment is based on the idea that giving employees skills, authority, resources, motivation, opportunity, as well as making them responsible for outcomes of their actions will contribute to their satisfaction and competence (Narmadha, 2015). It is believed that giving these factors would provide an opportunity to have responsibility empowers individuals and creates trust in your team. To participants, leadership is about empowerment by trusting the ability of people before giving them task, space, time and resources to do great work. That is, to ensure that people have the skills and capabilities necessary to be successful before giving them the support they need to perform well and achieve the objectives of organization. This gives people the scope to do things in their own way. Sit explained:

"Leadership is empowerment. When I work with boss, he was achieving operative officer, he is very hard working person, he empowers me, he always supports, he seems very strict but sometime he did some jocks and he has that kind of the quality of a leader, support, empower, give resources and then he guides at the same time." (Sit)

According to Waf's understanding, leadership is really depending on the leadership in her ability to empower to achieve goals. She openly stated:

"Leadership means empowerment others to work together with love to achieve the organization objectives. Empower people and motivate them to work for all as a single entity. When there is a disunion among workers, it would effect on their performance." (Waf) 


\section{Conclusion}

Based on a mixture of experience and learning, everyone may have his/her own intuitive understanding of leadership, which is difficult to capture in a succinct definition. Moreover, the way in which leadership is understood and defined is strongly influenced by one's theoretical stance. There are those who view leadership as the consequence of a set of characteristics or traits possessed by 'leaders', while others view leadership as a social process that stands out from group relationships. Such differing views would always result in having different opinions about the nature of leadership (Bolden, 2004).

The findings of this study provides a number of different perceptions in which Muslim women leaders understanding the meaning of leadership. They should have a clear vision and use it as a tool to inspire and motivate others, not to achieve the organization goals. Further, an active women leader should provide the encouragement and empowerment to motivate members to carry on. They should also be responsible for their actions, decisions, policies and implementation and be answerable for the possible consequences. Further, the findings provide understanding to the effect of role models on Muslim women's leadership aspirations and self-perceptions.

Based on the interview as well as direct inputs from the participants, there are a number of directions in which such research can continue in order to increase the understanding of leadership as this study investigated how Muslim women leaders perceive the meaning of leadership. This may provide future Muslim women leaders with insights into the characteristics of leadership in higher education.

First, future research could examine the perspective of Muslim women leaders in other settings than higher education, and in different regions of the world. In addition, the perspective of Muslim male leaders and non-Muslim leaders in higher education about the meaning of leadership and by comparing their perception and experiences with Muslim women leaders in higher education are other interesting topics for future research.

Another valuable area for further research is to examine the understandings of leadership in conjunction with leadership practices, providing insights into the relationships that may or may not exist between how women leaders view leadership and how they engage in leadership. This could be done quantitatively through using peer-assessed and selfassessed leadership behaviors.

\section{References}

Abd Aziz Yusof. (2000). "Perubahan dan Kepimpinan." Sintok: Universiti Utara Malaysia.

Abu-Tineh, A. (2013). Leadership Effectiveness in Jordanian Educational Institutions: A Comparison of Jordanian Female and Male leaders. Educational Management Administration \& Leadership 41(1) 79-94.

Ahmad, K. (2009). Leadership and work motivation from the cross cultural perspective. International journal of commerce and management, 19(1), 72-84.

Ali, J.S. (2007). "Leadership: An Islamic Perspective." Paper presented at the International Conference on Management from Islamic Perspective at Hilton Kuala Lumpur, Malaysia, 15-16 May, 2007.

AlSarhi, N. Z., Salleh, L. M., Mohamed, Z. A., \& Amini, A. A. (2014). The West and Islam Perspective of Leadership. International Affairs and Global Strategy, 18, 42-56.

Altbach, P. G., Reisberg, L., \& Rumbley, L. E. (2009). Trends in global higher education: Tracking an academic revolution.

Astin, A. W., \& Astin, H. S. (2000). Leadership reconsidered: Engaging higher education in social change. Battle Creek, MI: Kellogg Foundation.

Astin, H. S., \& Leland, C. (1991). Women of influence, women of vision. San Francisco, CA: Jossey-Bass.

Avolio, B. J., \& Gardner, W. L. (2005). Authentic leadership development: Getting to the root of positive forms of leadership. The Leadership Quarterly, 16(3), 315-338.

Beekun, R. I., \& Badawi, J. (1998). Leadership: An Islamic perspective. Int. Instit. Islamic Thought.

Berg, B.L. (2007). Qualitative research methods for the social sciences, (6th ed.). Boston, MA: Pearsons Education, Inc.

Bijur, P. (2000), The Energy of Leadership. In William Dauphinais, Grady Means \& Colin Price Price (Eds.), Wisdom of the CEO New York: Wiley. pp.167-174.

Bilen-Green, C., Froelich, K, A., \& Jacobson, S. W. (2008). The Prevalence of Women in Academic Leadership Positions, and Potential Impact on Prevalence of Women in the Professorial Ranks.2008 WEPAN Conference Proceedings.

Blanchard, K., Zigarni, P. \& Zigarni D. (2004). One minute manager. p 49 \&30.

Bolden, R. (2004). What is leadership? Leadership south west research report. Centre for Leadership Studies, Exeter, UK.

Bush, T. (2003). Theories of educational leadership and management. Sage.

Carroll, J. (2006). Americans prefer male boss to a female boss. Retrieved from http://brain.gallup.com.

Cole, N.D. (2004), "Gender differences in perceived disciplinary fairness", Gender, Work and Organization, Vol. 11 No. 3, pp. 254-79.

Conlin, M. (2003). The new gender gap. From kindergarten to grad schools boys are becoming to second sex. 
Crippen, C. (2005). The democratic school: First to serve, then to lead. Canadian Journal of Educational Administration and Policy, 47(5), 1-17.

Dahlvig, J. E., \& Longman, K. A. (2010). Women's leadership development: A study of defining moments. Christian Higher Education, $9(3), 238-258$.

Day, D. V., \& Antonakis, J. (Eds.). (2012). The nature of leadership. Thousand Oaks, CA: Sage.

Eagly, A. H., \& Carli, L. L. (2007). Through the labyrinth: The truth about how women become leaders. Boston, MA: Harvard Business School Press. Education, Vol. 27 No. 3, pp. 287-95.

Eagly, A., Makhijani, M., \& Klonsky, B. (1992). Gender and the evaluation of leaders: A meta-analysis. Psychological Bulletin, 111, 3-22. doi: 10.1037/0033-2909.111.1.3

Gardner, W. L., Avolio, B. J., \& Walumbwa, F. O. (2005). Authentic leadership development: Emergent trends and future directions. In W. L. Gardner, B. J. Avolio, \& F. O. Walumbwa (Eds.), Authentic leadership theory and practice: Origins, effects, and development (pp. 387-406). Oxford, UK: Elsevier Science.

Goodchild, L. F. (2002). Higher education as a field of study. In J. J. F. Forest \& K. Kinsner (Eds.), Higher education in the United States (pp. 303-309). Santa Barbara: ABC-CLIO.

Hall, A.T., Blass, F.R., Ferris, G.R. and Massengale, R. (2004) 'Leader reputation and accountability in organizations: implications for dysfunctional leader behavior', The Leadership Quarterly, Vol. 15, pp.515-536.

Hassan, Z., \& Silong, A. D. (2008). Women leadership and community development. European Journal of Scientific Research, 23(3), 361-372.

Joasil, L. G. D. (2008). A study into the relationship between observed and model values of men and women leaders in higher education. ProQuest.

Joyce, P., \& O'Boyle, C. (2013). Sustaining Academic Leadership in Higher Education.

Kaplan, R. E. (1996). Forceful leadership and enabling leadership: You can do both (No. 171). Center for Creative Leadership.

Kraines, G. (2001). Accountability leadership: How to strengthen productivity through sound managerial leadership: Career Press.

Kruse, K. (2013). What Is Leadership? Forbes Magazine.

Lukas, C. V., Holmes, S. K., Cohen, A. B., Restuccia, J., Cramer, I. E., Shwartz, M., \& Charns, M. P. (2007). Transformational change in health care systems: an organizational model. Health care management review, 32(4), 309-320.

Mark, T. (1997). Mastering People Management, Build a Successful Team: Motivate, Empower and Lead People. p 29 \& 31.

Marshall, J. (1984). Women Managers: Travelers in a Male World Chichster: John Wiley and Sons Inc.

Matei, L., \& Vazquez-Burguete, J. L. (2012). Permanent Study Group: Public and Nonprofit Marketing: Proceedings (Vol. 33). Matei Lucica.

Merriam, S. B. (1998). Qualitative research \& case study applications in education. San Francisco: Jossey-Bass.

Merriam, S. B. (2009). Qualitative research: A guide to design and implementation. San Francisco, CA: Jossey-Bass.

Morley, L., \& Crossouard, B. (2014). Women in Higher Education Leadership in South Asia: Rejection, Refusal, Reluctance, Revisioning.

Narmadha, K. (2015).Significance of Employee Empowerment and its Impact on Indian Companies. International Journal of Scientific Research, 4(6) No 2277 - 8179.

Northouse, P. G. (2010). Leadership: Theory and practice (5th ed.). Thousand Oaks, CA: SAGE.

Nye, J. S. (2008). The powers to lead. New York, NY: Oxford University Press.

OBE, N.J. (2013). Women Country Leaders in Higher Education 2013, Published by. www.women-count.org.

Paustian-Underdahl, S. C., Walker, L. S., \& Woehr, D. J. (2014). Gender and perceptions of leadership effectiveness: A meta-analysis of contextual moderators.

POPA, B.M. (2012).The Relationship between Effective Leadership and Organizational Performance,Journal of Defense Resources Management, Vol. 3, Issue 1(4) 2012.

Richardson, W. C. (2000). In A. W. Astin, \& H. S. Astin (Eds.), Leadership reconsidered: Engaging higher education in social change. Battle Creek, Ml: Kellogg Foundation.

Rosser, V. J. (2003). Faculty and staff members' perceptions of effective leadership: Are there differences between women and men leaders?. Equity \&Excellence in Education, 36(1), 71-81.

Sathye, M. (2004, September). Leadership in higher education: a qualitative study. In Forum Qualitative Sozialforschung/Forum: Qualitative Social Research (Vol. 5, No. 3).

Schafer, William D. (2000). Educating Applied Assessment Professionals at the Masters Level. p. 1 - 8. U.S.A.; Maryland.

Shahtalebi, S., Yarmohammadian, M. H., \& Ajami, S. (2011). Women's success factors from leadership in higher education. ProcediaSocial and Behavioral Sciences, 15, 3644-3647.

Sharma, S., Sun, H \& Kannan, S. (2012). A Comparative Analysis on Leadership Qualities of School Principals in China, Malaysia \& India. International Online Journal of Educational Sciences, 2012, 4 (3), 536-543.

Smith, J.A., Flowers, P. \& Larkin, M. (2009). Interpretative phenomenological analysis: theory, method and research. Los Angeles, Sage.

Sousa, D. (2015). The Leadership Brain: Strategies for Leading Today's Schools More Effectively. Skyhorse Publishing, Inc..

Tafvelin, S. (2013). The Transformational Leadership Process: Antecedents, Mechanisms, and Outcomes in the Social Services.

Turner, P. K., Norwood, K., \& Noe, C. (2013). A woman with a plan: Recognizing competencies for ascent to administration in higher education. NASPA Journal about Women in Higher Education, 6(1), 22-47. 
Unin, N., \& Dirkx, J. M. (2011). Learning to Lead as Learning to Learn: The Experiences of Malay Women at Malaysian Public Universities. In Conference Paper presented at the.

Vilkinas, T., Leask, B., \& Ladyshewsky, R. (2009). Academic leadership: Fundamental building blocks [Resource book]. Strawberry Hills, New South Wales: Australian Learning and Teaching Council.

Walker, S. (2004). Women and Leadership: A Female Private Institute for Higher Education, Al Nour College, in Saudi Arabia (Doctoral dissertation, King's College London).

Williams, R. (2012, December 15). Why women may be better leaders than men. Psychology Today. Retrieved from http://www.psychologytoday.com/blog/wired-success/201212/why-women-may-be-better-leadersmen.

Williamson, T. (2005) Work-based learning: a leadership development example from an action research study of shared governance implementation. Journal of Nursing Management. Vol. 13. No. 6. pp 490-499.

Willig, C. (2001). Introducing qualitative research in psychology: Adventures in theory and method. Buckingham: Open University Press.

Won-joo, Y. \& Mulhern, F. (2009). "Leadership and the Performance of People in Organizations: Enriching Employees and Connecting People." Leadership and Organization Development Journal, (2009).

Yielder, J., \& Codling, A. (2004). Management and leadership in the contemporary university. Journal of higher education policy and management, 26(3), 315-328.

Yin, R. K. (1994). Case Study Research: Design and Methods, 2nd eds. Thousand Oaks, London and New Delhi: Sage Publications.

Yukl, G. \& Van Fleet, D. D. (1992). Theory and research on leadership in Organizations. In Marvin D. Dunnett and Leaetta M. Hough (eds.), Handbook of Industrial and Organizational Psychology (pp. 147-197). Palo Alto, CA: Consulting Psychologist Press.

Yukl, G. (2006). Leadership in Organizations. Upper Saddle River, NJ: Pearson Education.

Yukl, G., (2010). Leadership in organizations (7th ed.). Upper Saddle River, NJ: Pearson Education, Inc.

Zeitchik, S. (2012). 10 Ways to Define Leadership. Business News Daily.

Zughoul, M. R., \& Hussein, R. F. (1985). English for higher education in the Arab world: A case study of needs analysis at Yarmouk University. The ESP journal, 4(2), 133-152. 